\title{
Improving the efficiency of resource potential use is an urgent task of the agro - industrial complex
}

\author{
Elena Krasnoperova* \\ South Ural state agrarian University, Troitsk., Russia
}

\begin{abstract}
The Russian economy is not going through an easy time. Production volumes and efficiency are growing slowly, against this background, a pleasant exception is the situation of the agro-industrial complex. In terms of export revenue, agriculture ranks 2 nd among all industries. Of course, the income from the export of agricultural raw materials is several times less than the income from the export of energy resources. However, a positive trend and good prospects for increasing export potential are important here. The article suggests measures to adjust the economic and social policy in the sphere of agriculture in the Chelyabinsk region. The policy of declaring small rural settlements not promising is not justified. All these areas of innovation in the agroindustrial complex should not be applied separately, but in combination. Such measures will provide a greater synergy effect than isolated measures.
\end{abstract}

\section{Introduction}

The Russian economy is not going through an easy time. Production volumes and efficiency are growing slowly, against this background, a pleasant exception is the situation of the agro-industrial complex. Not only is there no reduction in grain production, but there is also a steady growth in grain production, including its export potential. In terms of export revenue, agriculture ranks 2 nd among all industries. Of course, the income from the export of agricultural raw materials is several times less than the income from the export of energy resources. But here a positive trend and good prospects for increasing export potential are important $[2,8,16,17]$.

The bulk of the country's agribusiness profits come from the sale of food grains, mainly spring wheat. Importers of agricultural products are countries of Asia, Africa and Europe. Recently, our country has significantly pushed the position of the United States, which is the main exporter of food to the world market.

It should be noted that we mainly export spring wheat, which is a raw material for many branches of the food industry. Meanwhile, many countries, including the CIS (Kazakhstan), are increasing exports of not only raw materials, but also products with high added value

\footnotetext{
${ }^{*}$ Corresponding author: ea.g@mail.ru
} 
(such products include flour, cereals, feed). Exporting products with high added value can solve economic and social problems: create new jobs, increase rural incomes, and stabilize the social situation in small towns and rural settlements. We believe that such development in the activities of the agro-industrial complex should continue to be given priority.

The resource potential should be understood as a set of land plots, their structure, fertility, qualification of personnel, including workers, specialists and management personnel, scientific workers, availability of material and technical resources and their condition.

\section{Data and Methods}

The object of research is organizational and economic processes that characterize the environmental and social aspects of the quality of agricultural raw materials and food products. In the course of the research, economic-statistical, abstract-logical and other methods were used.

\section{Methods or Model}

The development of the agro-industrial complex in the Chelyabinsk region is in line with the General development of the country's agro-industrial complex. Macaroni factory JSC "Makfa", cereal company "Uvelka", JSC "Magnitogorsk combine of bread productsSITNO", are known not only outside the region, but also in the CIS countries. Further development of the export direction of the agro-industrial complex is hindered by a lack of investment.

Currently, the share of the budget allocation of the agro-industrial complex does not exceed 3-3.5\%. At the same time, even far from rich CIS countries (Belarus, Kyrgyzstan) allocate $8-10 \%$ for the development of agriculture. It should be noted that agricultural holdings, with rare exceptions, still prefer not to invest in scientific research, preferring imported seeds, technologies and breeding products. For example, JSC "Agroholding Ariant" purchased technological equipment and breeding young pigs in Canada, but here we are talking not even about tens, but hundreds of millions of dollars. The existing agricultural research Institute in the region is not able to provide seeds and high production of cereals and forage crops. In addition, their price is quite high, and not all agricultural enterprises and farms are able to purchase them. Most of them make do with ordinary seeds, and this is an obvious course for backwardness in the future. The same can be said about LLC "Ravis-Sosnovskaya poultry farm", specializing, respectively, in the production and processing of poultry meat.

Natural and economic conditions of the region allow you to grow many agricultural crops here: spring wheat, rye, legumes. The above does not mean that most of the problems of agriculture and agriculture have been solved or are being solved successfully. It seems to us that further innovation should be linked to better use of the resource potential.

In this regard, it seems to us that it is appropriate to evaluate the technology of production of livestock products from different positions: economic, environmental, social and other positions. We suggest evaluating existing technologies in this way. From an economic point of view, such indicators as labor productivity, market demand for the product and its price, the capital intensity of the industry, the payback period of investment, profitability, and others are of interest. From an environmental point of view, it is important to take into account the usefulness and safety of food, the impact of technologies on the environment and veterinary safety. 
Land $\rightarrow$ technology $\rightarrow$ raw $\rightarrow$ product $\rightarrow$ storage and processing $\rightarrow$ wholesale and retail trade

Scheme 1. Assessment of livestock production technology.

The land is considered not just as an object of production, but taking into account the natural geographical area, soil fertility, solar radiation, the amount of precipitation and their uniformity throughout the year, the number of frost-free days and the number of days with a daily temperature above $+10^{\circ} \mathrm{C}$.

In General, the natural resource potential of the region, as noted, allows you to cultivate the main agricultural crops. However, over the past 25 years, more than 75 thousand hectares of arable land have not been processed in the region. The main reason for this is that farmers who became owners of land plots were unable to conduct their own production due to the lack of material and technical base or its wear and tear.

It is the land and its accompanying factors that form the unique qualities of individual products. For example, Crimean wines, Vologda oil, Tambov ham, Kurgan geese are known far beyond their regions. Attempts to move their production to other zones were not successful. The production technology takes into account the totality of modern machines and equipment, their use during the year, professional competence of employees and management personnel, as well as the use of mineral fertilizers and feed additives, plant and animal protection products from pests. Modern technologies are currently available to large holding companies, such as the agricultural firm "Ariant", the cereal company" Uvelka", JSC" Magnitogorsk bread products plant - SITNO", Churilovsky greenhouse plant - LLC Agrocomplex"churilovo". All of them are produced on a modern scientific basis. They have well-established production, a clear organization of labor and the latest technological equipment. These are highly profitable enterprises focused on domestic and international markets. Their most important disadvantage is that they work on imported equipment, with imported seeds and imported breeding young. A big disadvantage is environmental safety. And first of all, the removal of manure and manure.

\section{Results}

Taking into account the current situation, it is necessary to increase the pace of support for agribusiness and agriculture at the expense of state and regional budgets for business innovation. In particular, the sale of fuel at preferential prices for the period of intensive agricultural work, financing research in the field of breeding and seed production, improving technologies, etc.

It needs to improve existing technologies for agricultural production, storage and processing, and bring them closer to world standards. In this regard, research institutes, higher educational institutions and agricultural Universities that are engaged in the development of new machines and equipment and the development of modern technologies need all possible support. This will increase the productivity of the land by at least $30-40 \%$. In particular, for the Chelyabinsk region, the prospect of getting 23-25 C. of grain per ha, and 40-50 C. of feed per unit ha will become quite real.

It is advisable to increase investments in the social sphere (construction of roads, medical and obstetric centers, gasification of villages). We believe that first of all we should consider improving the skills of managers, agricultural specialists and ordinary workers. In some cases, you can go to the construction of modern housing for agricultural workers with the possibility of buying it into private ownership.

Previously acquired knowledge and experience quickly become outdated. This is all the more justified, since the country has destroyed the system of training workers in mass 
professions (tractor drivers, drivers, livestock breeders, beekeepers, gardeners and vegetable growers). This also applies to the modern system of training specialists and fish workers. Bachelor's degree provides higher education, but does not fully meet the modern requirements for a specialist. After all, practical undergraduate training is limited to 4-4. 5 years, which is clearly not enough for seed production, breeding, etc.

The weak link in the development of agriculture is the lack of modern storage facilities and refrigerators. This leads to the fact that up to a third of vegetables and fruits die before reaching the consumer. As a result, prices on the domestic market will double or triple by April-may. According to the scientists of the Chelyabinsk Institute of fruit growing, the region could be fully provided with apples and sharply reduce the import of stone crops, since they grow well in this region.

This means that large investments are needed for the construction and equipment of storage facilities for vegetables and fruits. Food importers expect to buy fruits, vegetables, and berries even when the country has received a good collection of these goods. Prices for imported apples and fruits are consistently high. At the same time, domestic producers cannot sell their crops in the country, because retail chains refuse to buy domestic products even at low prices. In our opinion, there is a need for state regulation, in particular, first of all, the purchase of domestic products should be carried out.

The state of trade deserves a special discussion. Currently, this sphere of activity is monopolized by large network companies. They control trade not only in regional and large industrial centers, but also have infiltrated urban settlements and district centers.

For example, in the city of Troitsk, Chelyabinsk region, with a population of less than 80 thousand, there are currently 5 network companies operating. Local agricultural producers are not able to get into these retail chains, because they require rhythmic deliveries, standardization of products, packaging and preparation for sale. None of this is available to local manufacturers. In addition, payment for the delivered products is made after the sale, which actually leads to the fact that the payment is delayed for 1-1. 5 months. Meanwhile, the task of local agricultural producers is to grow and supply the necessary range of food to trade.

We support the view that retail chains should not be included in urban settlements with a population of up to 50 thousand people, and especially rural settlements. Therefore, it is necessary to support small trade enterprises, consumer cooperatives and owners of small shops that provide for the needs of the local population.

It is necessary to create opportunities for young people to learn working professions locally, which does not suit employers, as labor productivity is reduced. Employers would like to deal with ready-made employees with relevant knowledge, experience and skills [1, $5,10,19]$.

An integral element of the resource potential is the human resource potential. The human resource potential has undergone many negative phenomena. For example, many farmers who became the head of the corresponding organizational and legal formation were not ready for market conditions. It is one thing to work in rural areas and be an expert in your business, but it is another to be able to organize production in accordance with market demands, clearly respond to all legal changes, be able to forecast and manage.

The social policy of the state in relation to the village needs radical changes. Over the past 20-25 years, the number of schools, medical and midwifery centers has significantly decreased, sports activities have been transferred to a commercial basis, many cultural centers have ceased to function, or are dragging out a miserable existence. This situation has led to mass migration of the most able-bodied population to cities and industrial centers.

Young people, especially men, are looking for work in major cities or working shifts in the North. Lack of local employment and low pay is the main reason for youth migration. 
Another reason is that the sphere of culture and leisure has been destroyed. For example, the number of rural schools has decreased by 126 units, obstetric units to 80 units. Rural stadiums function only in district centers and large villages $[3,9,14,20]$.

When a rural locality is declared not promising, schools, medical and midwifery centers, libraries, and retail establishments are closed, the village is doomed to extinction. The reference to the fact that the transportation of students to other educational institutions is free of charge is not very clear. Daily transportation of a child aged 7-10 years for 10-20 $\mathrm{km}$ to school is tedious, in addition, he must wait for the end of the training of children from high school. Not all parents agree with this statement of the issue and are forced to change their permanent residence. References to optimizing the cost of maintaining schools, midwifery centers, and libraries are not always justified. Of course, every schoolchild's education in rural areas is more expensive. But here important circumstances are overlooked: migration of young people, arable land around abandoned settlements is not cultivated, weeds and shrubs are overgrown, haymaking and grazing for livestock are not used. This is nothing more than a deterioration in the use of the resource potential of the agro-industrial complex in the region.

Thus, the existing social policy in relation to the village was not quite well-off and needs to be adjusted. Agriculture no less than other sectors needs innovative activities that affect the main aspects of agricultural production and the social sphere.

\section{Discussion and conclusion}

The facts we have analyzed are presented in the following table.

Table 1. Characteristics of the resource potential of the agro-industrial complex of the Chelyabinsk region.

\begin{tabular}{|c|c|c|}
\hline Kind of resources & Dignities & Disadvantages \\
\hline Land plots & $\begin{array}{l}\text { Enough fertile land to grow } \\
\text { cereals, vegetables and } \\
\text { forage crops }\end{array}$ & $\begin{array}{l}\text { Availability of uncultivated } \\
\text { land, lack of organic and } \\
\text { expensive mineral fertilizers, } \\
\text { availability of free arable land }\end{array}$ \\
\hline Labor potential & $\begin{array}{l}\text { Availability of zonal } \\
\text { research institutes, higher } \\
\text { and secondary agricultural } \\
\text { education, the desire to } \\
\text { engage in agriculture, the } \\
\text { average level of } \\
\text { qualification of workers }\end{array}$ & $\begin{array}{l}\text { Poor knowledge of the market } \\
\text { economy of managers and } \\
\text { heads of farms, high } \\
\text { stratification of households by } \\
\text { income level, high } \\
\text { unemployment of the rural } \\
\text { population }\end{array}$ \\
\hline $\begin{array}{l}\text { Organizational and } \\
\text { technological potential }\end{array}$ & $\begin{array}{l}\text { High efficiency of holding } \\
\text { companies for the } \\
\text { production and processing of } \\
\text { pork and poultry products, } \\
\text { cereals companies, } \\
\text { greenhouses }\end{array}$ & $\begin{array}{l}\text { Moral and physical wear of } \\
\text { agricultural machinery. Many } \\
\text { livestock housing facilities } \\
\text { have ceased to exist }\end{array}$ \\
\hline
\end{tabular}

We believe that in managing the development of agriculture, it is not possible to do without forecast activities for the future and current short-term planning for 2-3 years. The very sphere of agricultural activity assumes that current planning is an objective reality. In agriculture, it is necessary to observe the alternation of crops of different crops. For 
example, sugar beet and sunflower crops strongly Deplete soil fertility, so it is recommended to return to their crops, not earlier than 5-7 years.

It is necessary to combine the development of crop production with animal husbandry. Crop production provides the livestock industry with feed and waste from the main products, and those in turn, organic fertilizers. Income from the sale of crop products is not received regularly, usually at the end of the year. The sale of milk and animal meat is more regular and planned, which provides the farm with an influx of funds. Animal husbandry increases employment of the rural population throughout the year - this means that household income is supplemented by wages on a regular basis. In turn, the state should determine what assortment and volumes the population of the region needs in food products, the timing of their entry into the market, etc. $[5,11,13,18]$.

The state should ensure a minimum purchase price for food raw materials. In other words, the state guarantees that the planned volume will be in demand from the manufacturer at least at a certain minimum price. The minimum price includes all production costs and taxes, plus a minimum profit margin of $10-15 \%$. The part of the product that is grown over the plan may not be in demand by the state, which means that it is the risk of the manufacturer and he acts with it at his discretion.

Given the rather difficult socio-economic situation of the rural population, we believe that measures to optimize production costs due to low wages have been exhausted. Wages in agriculture must grow at a faster pace than in other sectors of the national economy, otherwise we will lose the remaining part of our employees and even new investments in the development of the social sphere will not be able to attract and secure young people in rural areas.

We must do everything possible to promote the development of private farms by providing free land for grazing and forage. Employers could provide their machinery at a reasonable cost in the use of its employees and representatives of the social sphere. This will increase the volume of agricultural products, especially livestock, saturating them with quality food $[4,6,12,18]$.

It should be noted that from an environmental point of view, the products of holding companies are inferior in their food and taste characteristics to the products of private farms, farms and ordinary agricultural enterprises. This means that all organizational and legal forms and therefore should be supported and helped in every possible way by the owners of small and medium-sized enterprises that produce agricultural products.

Thus, all these areas of innovation in the agro-industrial complex should not be applied separately, but in combination. Such measures will provide a greater synergy effect than isolated measures.

These are, in our opinion, the main directions for better use of the resource potential of the agro-industrial complex of the region.

\section{References}

1. V. M. Bautin, Economics of agricultural and processing enterprises, 5 (2016)

2. A. N. Galatov, E. A. Krasnoperova, A.V. Kobylin, Zootechnia, 10 (2013)

3. A. I. Zharinov, M. S. Aliyev, A. S. Dadykin, Meat industry, 4 (2016)

4. Z. V. Nikitina, Agrarian Bulletin of the Urals, 9 (2008)

5. V. N. Ivanova, S. N. Seregin, A.V. Novoseltseva, Food industry, 4 (2016)

6. V. G. Litovchenko, A. N. Galatov, E. A. Krasnoperova et al., Feeding of farm animals and feed production, 4 (2015)

7. E. A. Krasnoperova, Scientific notes of the Kazan state Academy of veterinary medicine named after N. E. Bauman, 4 (228) (2016)

8. E. A. Krasnoperova, J. A. Yuldashbaev, Agricultural science, 3 (2016) 
9. Krasnoperova, E. A., Bulletin of the Novosibirsk state agrarian University, 3 (44) (2017)

10. E. A. Krasnoperova, Yu. A. Yuldashbayev, Proceedings of the Kuban state agrarian University, 64 (2017)

11. A. A. Kubyshko, A.V. Anisimov, Meat industry, 4 (2016)

12. I. Kulikov, I. Minakov, Agro-industrial complex: Economy and management, 2 (2016)

13. Z. V. Nikitina Agrarian Bulletin of the Urals, 9 (2008)

14. A.V. Anisimov, Beef industry, 4 (2016)

15. N.A. Bogdanov Hygiene and sanitation. 2 (95) (2016)

16. A. V. Borodin, Economy of agrarian and processing enterprises, 3 (95) (2016)

17. A. A. Varlamov Management of land resources, (Moscow, Kolos, 2004)

18. I. Kulikov, AIC: Economics, management, 2 (2016)

19. I. A. Zektser, Science and Life, 3 (2016)

20.Z. V. Nikitina, Agrarian bulletin of the Urals, 9 (2008) 